\title{
Mullerian anomalies: a cause of primary amenorrhea
}

\author{
Rajani M. Parikh*, Kanaklata Nakum, Gunvant K. Kadikar, A. V. Gokhle
}

Department of Obstetrics and Gynecology, Government Medical College, Bhavnagar, Gujarat, India

Received: 13 July 2013

Accepted: 4 August 2013

\section{*Correspondence:}

Dr. Rajani M. Parikh,

E-mail: rajnimaulik@yahoo.com

(C) 2013 Parikh RM et al. This is an open-access article distributed under the terms of the Creative Commons Attribution Non-Commercial License, which permits unrestricted non-commercial use, distribution, and reproduction in any medium, provided the original work is properly cited.

\section{ABSTRACT}

Background: The objectives of this study were to determine the etiologic causes of amenorrhea, the prevalence of müllerian anomalies as a cause of primary amenorrhea and the different varieties of müllerian anomalies causing primary amenorrhea.

Methods: This study included all the women presenting with primary amenorrhea who presented to the department of obstetrics and gynecology, Sir T Hospital and Government Medical College, Bhavnagar from $1^{\text {st }}$ January 2010 to $30^{\text {th }}$ June 2012.

Results: The causes of primary amenorrhea of our study due to obstructive anomalies were $37.72(\mathrm{n}=5)$ and müllerian agenesis were $57.14 \%(n=8)$ and androgen insensitivity $7.14(n=1)$.

Conclusions: Mullerian agenesis is the most prevalent cause of primary amenorrhea in our study.

Keywords: Primary amenorrhea, Mullerian agenesis, Obstructive mullerian anomalies

\section{INTRODUCTION}

Amenorrhea is the absence of a menstrual period in a woman of reproductive age. The term is derived from Greek: $a=$ negative, men $=$ month, rhoia $=$ flow. ${ }^{1}$ Primary amenorrhea (menstruation cycles never starting) may be caused by developmental problems such as the congenital absence of the uterus, or failure of the ovary to receive or maintain egg cells. Also, delay in pubertal development will lead to primary amenorrhea. It is defined as an absence of secondary sexual_characteristics by age 14 with no menarche or normal secondary sexual characteristics but no menarche by 16 years of age. ${ }^{2}$ The incidence of Primary amenorrhea is: $0.3 \%$ (Clinical Knowledge Summaries, 2009). ${ }^{3}$

By compartment: The reproductive axis can be viewed as having four compartments: 1. Outflow tract (uterus, cervix, and vagina), 2. Ovaries, 3. Pituitary gland and 4. Hypothalamus.

\section{METHODS}

This study was done at Sir T hospital and Government Medical College, Bhavnagar from $1^{\text {st }}$ January 2010 to 30th June 2012. The objective was to determine:

- the etiologic causes of amenorrhea

- the prevalence of müllerian anomalies as a cause of primary amenorrhea

- the different varieties of müllerian anomalies causing primary amenorrhea

The inclusion criterion was: H/o primary amenorrhea.

The exclusion criterion was: Pregnancy and age <14 yrs.

Patients with features of Turner's syndrome or absent vagina were to be included even if they presented before 14 years of age. 
A careful history was taken to determine psychological or emotional stress, family history for genetic anomalies. Clinical assessment was done for signs of physical problems with focus on nutritional status and abnormal growth, per abdomen, local hymen examination and per rectal examination was done in all patients to determine presence or absence of uterus. Ultrasonography was done to determine presence of uterus and its anomalies, endometrial thickness and associated mass if any. CT/MRI were done in some cases if USG seemed inadequate

RBS, S. LH, S.FSH, S. Prolactin and S. TSH were done depending on patient's clinical examination. Depending on the assessment, pts were further investigated by Laparoscopy. Due to lack of facility cytogenic evaluation was done in only 2 cases. Further investigations were aimed to elucidate associated abnormalities like renal and skeletal.

Once the diagnosis was established patient was treated and counseled accordingly.

\section{RESULTS}

During this period total number of patients attending the gynaec outpatient department was 60958. We had 14 patients who presented with primary amenorrhea. The incidence of primary amenorrhea in our institute was $0.02 \%$ which is very low.
Table 1: Age at presentation and marital status.

\begin{tabular}{|llll|}
\hline Causes & $\begin{array}{l}\text { Number } \\
(\%)(\mathbf{n}=14)\end{array}$ & $\begin{array}{l}\text { Age at registration } \\
(\text { years }) \\
\text { Mean } \pm \text { SD [range] }\end{array}$ & $\begin{array}{l}\text { Marital } \\
\text { status } \\
(\boldsymbol{n}) \\
\mathbf{S} \text { M D }\end{array}$ \\
\hline $\begin{array}{l}\text { Imperforate } \\
\text { hymen }\end{array}$ & $4(28.57)$ & $15.75 \pm 1.7(14-18)$ & 4 \\
\hline $\begin{array}{l}\text { Transverse } \\
\text { vaginal } \\
\text { septum }\end{array}$ & $1(7.14)$ & $16 \mathrm{ND}$ & 1 \\
\hline $\begin{array}{l}\text { Müllerian } \\
\text { agenesis }\end{array}$ & $8(57.14)$ & $19.25 \pm 3.2(16-25)$ & 511 \\
\hline $\begin{array}{l}\text { Androgen } \\
\text { insensitivity }\end{array}$ & $1(7.14)$ & $16 \mathrm{ND}$ & 1 \\
\hline
\end{tabular}

$(\mathrm{S}=$ single, $\mathrm{M}=$ married, $\mathrm{D}=$ divorcee $)$

It was observed that patients with obstructive anomalies presented earlier than those with müllerian agenesis as they developed complaints because of obstruction.

The observation table with presenting complaint is shown below (Table 2).

It was seen that only patients with müllerian anomalies presented with amenorrhea as a primary complaint while in others the presenting symptom varied.

Table 2: Observation with presenting complaint.

\begin{tabular}{|llllll|}
\hline Diagnosis & $\begin{array}{l}\text { Total } \\
\text { patients }\end{array}$ & Abdominal pain & $\begin{array}{l}\text { Urinary } \\
\text { complaints }\end{array}$ & Abdominal mass & $\begin{array}{l}\text { Primary } \\
\text { amenorrhea }\end{array}$ \\
\hline Imperforate hymen & 4 & $\begin{array}{l}2 \text { (1 acute } \\
\text { abdomen, } 1 \\
\text { recurrent pain) }\end{array}$ & 1 (retention) & $\begin{array}{l}1 \text { (18-20 wks mass } \\
\text { arising from pelvis) }\end{array}$ & 0 \\
\hline $\begin{array}{l}\text { Transverse vaginal } \\
\text { septum }\end{array}$ & 1 & 1 & - & - & - \\
\hline Müllerian agenesis & 8 & - & $\begin{array}{l}\text { 1 (Incontinence } \\
\text { since birth) }\end{array}$ & - & 7 \\
\hline Androgen insensitivity & 1 & - & - & 1 (inguinal hernia) & - \\
\hline
\end{tabular}

Table 3: Comparison with other studies.

\begin{tabular}{|lll|}
\hline Diagnosis & $\begin{array}{l}\text { Incidence in } \\
\text { our study }(\%) \\
(\mathbf{n = 1 4})\end{array}$ & $\begin{array}{l}\text { Incidence in } \\
\text { Tanmahasamut } \\
\text { et al 2012 } \\
(\mathbf{n}=\mathbf{2 9 5})\end{array}$ \\
\hline $\begin{array}{l}\text { Imperforate } \\
\text { Hymen }\end{array}$ & 28.57 & 2.0 \\
\hline $\begin{array}{l}\text { Transverse vaginal } \\
\text { septum }\end{array}$ & 7.14 & 0.3 \\
\hline $\begin{array}{l}\text { Müllerian agenesis } \\
\text { Androgen }\end{array}$ & 57.14 & $\begin{array}{l}39.7 \text { (most } \\
\text { common) }\end{array}$ \\
\hline \begin{tabular}{l} 
Ansensitivity \\
\hline
\end{tabular} & 7.14 & 5.1 \\
\hline
\end{tabular}

In our study müllerian agenesis $(58.17 \%)$ was the most common cause which was compatible with Tanmahasamut et al (Thailand). ${ }^{4}$ This is in contrast to American study by Reindollar et al. ${ }^{5}$ gonadal dysgenesis was commonest (48.5\%) -American study. This verified that racial and environmental factors played an essential part in the causes of primary amenorrhea.

Though the incidence of primary amenorrhea was quite low in our study but the incidence of transverse vaginal septum, müllerian agenesis and androgen insensitivity were quite compatible. 
Table 4: Incidence in relation to normal population.

\begin{tabular}{|c|c|c|c|}
\hline Diagnosis & $\begin{array}{l}\text { Incidence } \\
\text { in our study }(\%) \\
(n=60958)\end{array}$ & $\begin{array}{l}\text { Incidence } \\
\text { in general } \\
\text { population }\end{array}$ & Reference \\
\hline Primary amenorrhea & 0.022 & 0.3 & $\begin{array}{l}\text { Clinical Knowledge Summaries } \\
2009^{3}\end{array}$ \\
\hline Imperforate Hymen & $0.006(4$ in 60,958$)$ & 0.1 & Am J of Obstet and Gynec $2001^{6}$ \\
\hline $\begin{array}{l}\text { Transverse vaginal } \\
\text { septum }\end{array}$ & 0.001 ( 1 in 60,958$)$ & 2 in 100,000 female & Archieves Gynecol Obstet $2012^{7}$ \\
\hline Müllerian agenesis & $0.013(8$ in 60,958$)$ & $\begin{array}{l}1 \text { in } 4,000 \text { to } 5,000 \\
\text { female }\end{array}$ & J Negat Results Biomed $2006^{8}$ \\
\hline Androgen insensitivity & 0.001 ( 1 in 60958$)$ & 1 in 99000 & J Reprod Med ${ }^{9}$ \\
\hline
\end{tabular}

Table 5: Investigations for confirmation of diagnosis and management.

\begin{tabular}{|lllll|}
\hline Investigation & Total No. & diagnosis & Findings & Management \\
\cline { 3 - 4 } & \multirow{2}{*}{ USG } & $\begin{array}{l}\text { Imperforate } \\
\text { hymen }\end{array}$ & Hemetocolpos- 3 & drainage \\
\cline { 3 - 4 } & 1 & $\begin{array}{l}\text { Transverse } \\
\text { vaginal septum }\end{array}$ & $\begin{array}{l}\text { Hemetocolpos, low transverse } \\
\text { vaginal septum }\end{array}$ & $\begin{array}{l}\text { Drainage \& vaginal } \\
\text { reconstruction }\end{array}$ \\
\hline MRI & 1 & $\begin{array}{l}\text { Androgen } \\
\text { insensitivity }\end{array}$ & $\begin{array}{l}\text { Right testis in inguinal canal, } \\
\text { left testis intra abdominal }\end{array}$ & $\begin{array}{l}\text { Bilateral orchiectomy and } \\
\text { hernioplasty* }\end{array}$ \\
\hline MRI & 1 & & & \\
\hline
\end{tabular}

* Orchiectomy after pubertal development

Table 6: Patients with Müllerian agenesisInvestigations and management $(\mathrm{N}=8)$.

\begin{tabular}{|lllll|}
\hline $\begin{array}{l}\text { Investig } \\
\text { ation }\end{array}$ & $\begin{array}{l}\text { Uterus } \\
(\mathbf{N = 8})\end{array}$ & $\begin{array}{l}\text { Ovaries } \\
(\mathbf{N = 8})\end{array}$ & Vagina & Management \\
\hline $\begin{array}{l}\text { Laparosc } \\
\text { opy- 6 }\end{array}$ & $\begin{array}{l}\text { Absent- } \\
5\end{array}$ & $\begin{array}{l}\text { Normal- } \\
6\end{array}$ & Absent- 4 & Vaginoplasty* \\
\hline USG- 2 & $\begin{array}{l}\text { Rudimen } \\
\text { tary } \\
\text { horns- 3 }\end{array}$ & Streak- 2 & $\begin{array}{l}\text { Blind } \\
\text { pouch- 4 } \\
\text { (Septum- 1) }\end{array}$ & $\begin{array}{l}\text { Manual } \\
\text { compression }\end{array}$ \\
\hline
\end{tabular}

*Vaginoplasty before or soon after marriage

One patient in this group had associated anomalies with cleft palate, urinary incontinence and meningomyelocoele. Also a vertical septum was present in the vagina in her.

Müllerian agenesis affects only females. In almost all reports, karyotype of patients is that of normal 46, XX women. Rare chromosome abnormalities have been found associated with Müllerian aplasia, such as mosaicism, rearrangements/deletions. ${ }^{8}$

Cytogenic study was done in only 2 cases. One case of müllerian agenesis who showed streak gonads on laparoscopy (46 XX) and 1 case of androgen insensitivity (46XY).
Family history was present in 4 cases of müllerian agenesis (2 patients were sisters; 2 were first cousins paternal relation). In the one case of androgen insensitivity her mother's sister was also having androgen insensitivity.

\section{DISCUSSION}

Amenorrhea is a symptom, not a disease, and has a variety of causes. Clinical classification of amenorrhea into primary and secondary gives us a rough guide to etiology and prognosis. Primary amenorrhea is usually due to gross error in development of either uterus or ovaries, and is therefore not amenable to treatment. Genetic (39\%) and anatomic abnormalities (42\%) appear to be remarkable cause of primary amenorrhea. ${ }^{4}$

The true incidence of obstructive Müllerian anomalies is unknown, but is believed to be between $0.1 \%$ and $3.8 \%$. Incomplete canalization of the urogenital sinus with the Müllerian system can lead to imperforate hymen. A variety of hymenal abnormalities exist and this abnormality may present at different stages of life. After puberty, imperforate hymen presents in association with cyclic pain and amenorrhea. Physical examination often reveals a bulging hymen with a bluish hue. Some adolescents also present with painful urination, back pain, 
and painful defecation, as well as amenorrhea. Imperforate hymen must be differentiated from a low transverse vaginal septum; this can be accomplished with Valsalva. Imperforate hymen should bulge with Valsalva and transverse vaginal septum should not.

The exact etiology of transverse vaginal septum is unknown but its incidence has been reported to be 2 in 100,000 female live births making it one of the rarest anomalies of the female genital tract. ${ }^{7}$ The etiology of the condition is unknown, although most cases are thought to be the result of female sex-limited autosomal recessive transmission. In transverse vaginal septum a vertical fusion disorder exists between the Müllerian ducts and the urogenital sinus. The septa may occur at any level in the vagina with the following frequencies: $46 \%$, upper vagina; $40 \%$, mid vagina; and $14 \%$, lower vagina. Septa may be complete or incomplete. They are generally less than $1 \mathrm{~cm}$ in thickness, with thicker septa noted to be more common near the cervix. ${ }^{4}$ In our case study we had one patient with transverse vaginal septum, which was low variety. An imperforate transverse vaginal septum may present before or after puberty. Repair before puberty is associated with a high rate of vaginal stenosis, and re-repair with vaginal reconstruction may be required later for adequate menstruation and coital function. Postpubertal patients generally present with cyclic pain, vaginal discharge, abnormal menstruation, and development of pelvic mass. Magnetic resonance imaging is currently the gold standard for delineating the anatomy.

Mayer-Rokitansky-Kuster-Hauser (MRKH) syndrome consists of vaginal aplasia with other müllerian (i.e. paramesonephric) duct abnormalities. The frequency of congenital absence of vagina and uterus is not yet entirely clear, although reported incidences vary from 1 in 4,000 to 5,000 female births. Type I or The typical form is characterized by laparoscopic or laparotomy findings of symmetric muscular buds (the Müllerian remnants) and normal Fallopian tubes; this is referred to as the so-called Rokitansky sequence, where only the caudal part of the Müllerian duct (upper vagina and uterus) is affected. The type II or atypical form is marked by other malformations; these include vertebral, cardiac, urologic (upper tract), and otologic anomalies. In our study we had one patient of type II who had vertebral, urologic and facial anomaly. In both types, the extent of vaginal aplasia varies, ranging from virtually absent to virtually inconsequential. In our study vagina was seen to be present in four cases (of which one case had vertical vaginal septum) while it was totally absent in other 4 cases. Mayer-Rokitansky-KusterHauser syndrome usually remains undetected until the patient presents with primary amenorrhea despite normal female sexual development.

It is the second most common cause of primary amenorrhea. ${ }^{5}$ Though in our study müllerian agenesis $(58.17 \%)$ was the most common cause in our study. The frequency of type II is much greater. Though in our study Type I variety was found be more common. Familial clustering is reported with increasing frequency as was seen in our study.

The overall features clearly differentiate the MRKH syndrome from other defects of genital tract development such as androgen peripheral insensitivity (patients 46, $\mathrm{XY}$ ) or Turner's syndrome (patients $45, \mathrm{X}$ ).

As all the cases in the study were involving compartment I, diagnosis was produced by only simple clinical information, that is, medical history, physical examination, and reproductive hormonal profile. Cytogenic analysis was suggested in those with streak gonads and in case of androgen insensitivity. This is to identify the $\mathrm{Y}$ chromosome or its fragment(s). The gonads or gonadal ridges of these patients are at high risk of malignant transformation. As tumour transformation in gonadal ridge could occur at any age, the streak gonads should be removed in as soon as diagnosis is made. Except in case of androgen insensitivity syndrome, in which gonadectomy can be delayed until patient has completed pubertal development.

The limitations of this study are that it was conducted in a tertiary hospital so the study population were somewhat affected by referral patterns and what referring physicians were comfortable taking care of. Also the study population was small in comparison to other studies.

\section{CONCLUSION}

Racial, genetic and environmental factors appear do play a part in the causes of primary amenorrhea. Obstructive Müllerian anomalies are unusual and present most frequently in childhood and adolescence. A high index of suspicion is necessary for proper diagnosis. Clinicians who care for adolescents must consider Obstructive Müllerian anomalies in the differential diagnosis when abnormal bleeding, amenorrhea, or cyclic pelvic pain is present. Magnetic resonance imaging is currently the gold standard for delineating the anatomy. Goals of therapy in the care of young women with these anomalies are relief of the obstructive symptoms and restoration of normal menstrual egress and sexual function, with preservation of reproductive potential.

Gonadal dysgenesis is not common in androgen insensitivity and mullerian agenesis. Although Mullerian agenesis has psychologically devastating consequences, its physiological defects can be surgically treated in many cases. Following diagnosis, surgical intervention allows patients to have normal sexual function. Reproduction may be possible with assisted technique.

\section{REFERENCES}

1. Speroff L, Fritz MA. Clinical Gynecologic Endocrinology and Infertility. Lippincott, Williams \& Wilkins, 2005. p. 403ff. ISBN 0-7817-4795-3. 
2. Master-Hunter T, Heiman, DL. Amenorrhea: Evaluation and Treatment. American Family Physician 2006;73(8):1374-82.

3. Amenorrhoea, Clinical Knowledge Summaries, 2009. Available at http://cks.nice.org.uk/amenorrhoea. Accessed 12 March 2013.

4. Tanmahasamut P, Rattanachaiyanont M, Dangrat C, Indhavivadhana S, Angsuwattana S, Techatraisak K. Causes of primary amenorrhea: a report of 295 cases in Thailand. J Obstet Gynaecol Res. 2012 Jan;38(1):297-301.

5. Reindollar RH, Tho SPT, McDonough PG. Delayed puberty: an updated study of 326 patients. Trans. Gynecol. Obstet. Soc. 1989;8:146-162.
6. Burgis J. Obstructive Müllerian anomalies: Case report, diagnosis, and management. Am J Obstet Gynecol. 2001 Aug;185(2):338-44.

7. Deligeoroglou E, Iavazzo C, Sofoudis C, Kalampokas T, Creatsas G. Management of hematocolpos in adolescents with transverse vaginal septum. Arch Gynecol Obstet. 2012 Apr;285(4):1083-7.

8. Guerrier D, Mouchel T, Pasquier L, Pellerin I. The Mayer-Rokitansky-Küster-Hauser syndrome (congenital absence of uterus and vagina)-phenotypic manifestations and genetic approaches. J Negat Results Biomed. 2006 Jan 27;5:1.

9. Breech LL, Laufer MR. Obstructive anomalies of the female reproductive tract. J Reprod Med 1999:44:233-40.

DOI: $10.5455 / 2320-1770$. ijrcog20130926

Cite this article as: Parikh RM, Nakum K, Kadikar GK, Gokhle AV. Mullerian anomalies: a cause of primary amenorrhea. Int $\mathbf{J}$ Reprod Contracept Obstet Gynecol 2013;2:393-7. 